August 1986

\title{
Brief Reports: Depressive Phenomena in Infants
}

Vanshdeep Sharma, MD

Delaware State Hospital, New Castle Delaware

Follow this and additional works at: https://jdc.jefferson.edu/jeffjpsychiatry

Part of the Psychiatry Commons

Let us know how access to this document benefits you

\section{Recommended Citation}

Sharma, MD, Vanshdeep (1986) "Brief Reports: Depressive Phenomena in Infants," Jefferson Journal of Psychiatry. Vol. 4 : Iss. 2 , Article 9.

DOI: https://doi.org/10.29046/JJP.004.2.011

Available at: https://jdc.jefferson.edu/jeffjpsychiatry/vol4/iss2/9

This Article is brought to you for free and open access by the Jefferson Digital Commons. The Jefferson Digital Commons is a service of Thomas Jefferson University's Center for Teaching and Learning (CTL). The Commons is a showcase for Jefferson books and journals, peer-reviewed scholarly publications, unique historical collections from the University archives, and teaching tools. The Jefferson Digital Commons allows researchers and interested readers anywhere in the world to learn about and keep up to date with Jefferson scholarship. This article has been accepted for inclusion in Jefferson Journal of Psychiatry by an authorized administrator of the Jefferson Digital Commons. For more information, please contact: JeffersonDigitalCommons@jefferson.edu. 


\title{
Brief Reports
}

\section{Depressive Phenomena in Infants}

\author{
Vanshdeep Sharma, M.D.
}

Interest in childhood depression is demonstrated by an increasing amount of research in the area. A review of literature suggests that depression as a clinical entity is observable in children (1).

However, since the classic work on Anaclitic Depression by Rene Spitz, the existence of a similar disorder in infants remains in controversy. According to Bower (2), "Infancy is the period of life which begins at birth and ends with the use of language. In this sense, the duration of infancy is about 18 months." It is to this period of life that I shall confine myself in reviewing the pertinent literature on the subject.

In the $1960 \mathrm{~s}$, there was much discussion regarding the existence of childhood depression and whether this could be considered a clinical entity in terms of psychodynamic formulations. Rie, in his review maintained that childhood depression is not a valid concept, since the presence of an internalized superego was essential to depressive illness. Thus, children could not have a true depressive illness as they lack a well internalized superego, before adolescence $(3,4)$.

By the early 1970s, the view that childhood depression exists with overt depressive symptoms, was gaining recognition. Cytryn and McKnew reviewed the various schools of thought on childhood depression and proposed a classification system based on the assumption that the presentation of depressive symptoms reflected the developmental stage of the child in terms of the defenses available to cope with the depression (5).

The preponderance of thinking at the present time, is that childhood depression as a clinical entity exists in prepubertal and adolescent children. Empirical research has shown that both RDC and DSM-III criteria can identify children with major depression. Investigators have shown that children with "major depression" do respond to tricyclic antidepressants (6-8).

One of the difficulties facing researchers studying affective responses in infants is the development of methods of study which would reflect the role that emotions play in the everyday life of the infant. There is ongoing research to

Dr. Sharma wrote this paper while a fourth-year resident at Delaware State Hospital, New Castle, Delaware. 
develop and standardize tools to observe and assess emotional expression in infants $(9,10)$.

DSM-III states that a major depressive episode may begin at any age, including infancy. In enumerating the diagnostic criteria, while not commenting specifically on infants, it states that,

1. For children under six, dysphoric mood may have to be inferred from a persistently sad facial expression.

2. In children under six, at least three of the four symptoms should be present nearly everyday for a period of at least two weeks:

a. Failure to make expected weight gains,

b. Insomnia or hypersomnia,

c. Hypoactivity,

d. Signs of apathy (11).

Mahler (12) has noted that motor activity is the chief representor of affect in the preverbal child. In addition, Spitz has emphasized the importance of infant observation. He has done numerous studies and close observation of many groups of infants, in their own homes as well as in institutions. Anaclitic Depression is a syndrome described by Spitz as an "emotional deficiency disease" of infancy. In his original description (13) he stated that prolonged separation from the mother in the second half of the first year of life resulted in a characteristic syndrome. For this syndrome to develop, normal good relations between the mother and infant had to develop in the first half of the first year. Then, if the infant was deprived of the mother for at least three consecutive months, a characteristic picture unfolded: In the first month, the infant was weepy and demanding with clingy behavior toward observers making contact with him. In the second month, the weeping changed to wailing. The infant was insomniac and showed a decrease in weight. During the third month, the infant showed signs of withdrawal, shunned contact, tended to lie prone in his bed most of the time and motor retardation became pronounced. Some facial rigidity set in, which beyond the third month became firmly established. The infant's developmental quotient decreased. If the mother returned during this period of time, the picture improved.

Spitz also noted that if the separation of the infant from the mother persisted, then the syndrome of Anaclitic Depression merged into a condition which he called Hospitalism, described first in 1945. He distinguished these two conditions and stressed that Anaclitic Depression may be a transition to Hospitalism depending upon the length of separation (beyond three to five months) and on whether the emotional deprivation was partial or total (14-16).

The syndrome of Anaclitic Depression was distinguished by Spitz from Bowlby's concept of mourning. Bowlby, in describing the consequences of separation from the mother, has delineated three phases. In the first, the child protests and attempts to recover the mother (i.e., by loud cries, looking eagerly toward any sound which might prove to be his missing mother). This is the 
dominant response during the first few days following separation. In the second phase described by Bowlby, the infant seems to despair of recovering the mother but remains preoccupied with her. Gradually, the infant becomes apathetic and withdrawn. Finally, the infant appears to lose interest in the mother and seems to become emotionally detached from her.

Bowlby goes on to say that these three phases are related to central issues of psychoanalytic theory. The phase of protest is related to separation-anxiety, despair is related to grief and mourning, and detachment acts as a defense. He contends that these three are phases of a single process (17-19).

Bowlby's views are a matter of controversy and differ from those of other authors of psychoanalytic literature on several points. Helene Deutsch (20) has explicitly divorced these phases. She has stated that the early infantile anxiety is the small child's response to separation from the protecting and loving person. When the child is older (and more mature), mourning and grief are to be expected as a response to separation, in place of anxiety.

It should also be understood that Bowlby is essentially describing brief separations between mother and infant, and his time periods in no way relate to those mentioned by Spitz (13) in describing anaclitic depression. Bowlby also states that once reunited with the mother, the infant's detachment fades and after a period of time no residual can be detected. Spitz, on the other hand suspected that in his cases recovery was never complete. This suspicion of Spitz is well proven by Harmon et al (21). Their paper on anaclitic depression was a follow up study of "George." George had been placed in a residential nursery at age 8 days. Emde et al (22) documented his early development and at age 9 months noted that George suffered from anaclitic depression which subsequently lasted till age 17 months. Harmon et al in their paper, focused on George's development from age 20 months till 12 years. During this period they noticed that George was often clinically depressed. Although this picture is atypical in a number of ways (outstanding difference being that no normal mother-infant bonding occurred in the first few months), the authors have persuasively presented why their patient developed anaclitic depression and why this picture continued with remissions and exacerbations well into his prepubertal years.

There are other cases of depression in infants described in the literature. In a number of these cases, there was no physical separation between the mother and infant for any length of time. In the case described by Davidson (23), the patient (Kate, age 17 years) was intensively studied from age 4 months onward and showed evidence of depression at various stages of development. It is Davidson's hypothesis that if records of the infancy of a patient are available (as was the case with her patient), then one would be able to see signs in the infant's affective state that would be the infantile counterpart of that adult's experience of depression. Davidson classified the symptoms to look for in the infant's records. These were, "lassitude, repeated regurgitation, poor muscle control and excessive sleeping." 
Sleep is conceptualized by Engel and Reichsman (24) as one way in which an individual can withdraw from his environment; Brazelton (25) considers withdrawal into sleep as an early defense available to the infant. Engel and Reichsman have described their case who also was not separated from her mother. Their patient appeared to develop the syndrome (which the authors called "Depression of Infancy") during a period of estrangement between the patient and her mother in the first year of life, because she suffered from an obvious physical defect (gastric fistula). The authors were able to not only observe the patient's initial depression and subsequent recovery, but were also able to experimentally induce depression. They have detailed their method of inducing depression in the patient in their original work.

Earls (26) points out that the syndrome of non-organic failure to thrive (which is called the Reactive Attachment Disorder in DSM-III) can be considered as a depressive syndrome in infants. In these cases, listlessness and weight loss are almost invariably present.

\section{CONCLUSIONS}

There is little epidemiologic data to support the diagnosis of depression in infants. However, there appears to be accumulating evidence toward such a diagnosis.

Spitz $(13,14)$ has elaborated the psychodynamic development of the infant from the phase of narcissism (first three months) through pre-objectal relations (second three months) to the final stage of true object relations (six to nine months). For anaclitic depression to develop, a period of separation between the infant and mother, following good object relations, is necessary.

Spitz also argued that since the mother was the dominant partner in the mother-infant dyad, disorders of the mother's personality would be reflected in disorders of the infant. This is amply borne out by the cases of Davidson, Engel and Reichsman, and others. In each of these cases, there was no physical (quantitative) separation between the mother and infant, but rather the quality of the interaction between them was such that the various authors felt their patients were depressed. The cases mentioned here all show abnormal affective responses as a consequence of absent, lost, or deficient mother-infant interactions. The question of constitutional contribution by the infant to this interaction has been less well examined than the environmental-familial contribution. However, its empirical study in older children leaves no reason to believe that it should not be present in some infants.

\section{REFERENCES}

1. Kashani JH, Husain A, Shekim WO, et al: Current Perspectives on Childhood Depression. An Overview. Am J Psych 138:143-152, 1981

2. Bower, TG: A Primer of Infant Development. San Francisco, WH Freeman, 1977 
3. Rie, HE: Depression in childhood. A survey of some pertinent contributions. $J \mathrm{Am}$ Acad Child Psych 5:653-685, 1966

4. Cytryn L, McKnew DH, Burney WE: Depression in childhood. A re-assessment. Am J Psych 137:22-25, 1980

5. Cytryn L, McKnew DH: Factors influencing the changing clinical expression of the depressive process in children. Am J Psych 131:879-881, 1974

6. Frommer, EA: Treatment of childhood depression with antidepressant drugs. $\mathrm{Br}$ Med J 1:729, 1967

7. Puig-Antich J, Blaus S, Marx N, et al: Pre-pubertal major depressive disorder. J Am Acad Child Psych 17:695-707, 1978

8. Weinberg WA, Rutman J, Sullivan L, et al: Depression in children referred to an educational diagnostic center: Diagnosis and treatment. J Pediatr 83:1065, 1973

9. Gaensbauer TJ, Harmon RJ: Clinical assessment in infancy, utilizing structured playroom situations. J Am Acad Child Psych 20:264-280, 1981

10. Gaensbauer TJ: Regulation of emotional expression in infants from two contrasting environments. J Am Acad Child Psych 21:163-171, 1982

11. American Psychiatric Association; Diagnostic and Statistical Manual of Mental Disorders, Third Edition, Affective disorders, 205-224, Washington, DC, APA, 1980

12. Mahler MS, Pine F, Bergman A: The Psychological Birth of the Human Infant. New York, Basic Books, 1975

13. Spitz RA: Anaclitic depression. Psychoanal Study Child 2:313-342, 1946

14. Spitz RA: Hospitalism. An inquiry into the genesis of psychiatric conditions in early childhood. Psychoanal Study Child 1:53-74, 1945

15. Spitz RA: Hospitalism. A follow-up report. Psychoanal Study Child 2:113-118, 1946

16. Szurek SA: The child's needs for his emotional health, in Modern Perspectives in International Child Psychiatry. Edited by Howells JG. New York, Brunner/Mazel, 1969

17. Bowlby J: Grief and mourning in infancy and childhood. Psychoanal Study Child $15: 9-52,1960$

18. Bowlby J: "Separation," in Attachment and Loss, Vol 2. New York, Basic Books, 1973

19. Bowlby J: "Loss: Sadness and Depression," in Attachment and Loss, Vol 3. New York, Basic Books, 1980

20. Deutsch H: Absence of grief. Psychoanalytic Quarterly 6:12-22, 1937

21. Harmon RJ, Wagonfeld S, Emde RN: Anaclitic depression. A follow-up from infancy to puberty. Psychoanal Study Child 37:67-94, 1982

22. Emde RN, Polack PR, Spitz, RA: Anaclitic depression in an infant raised in an institution. J Am Acad Child Psych 4:545-553, 1965

23. Davidson J: Infantile depression in a "normal" child. J Am Acad Child Psych $7: 522-535,1968$

24. Engel GL, Reichsman F: Spontaneous and experimentally induced depressions in an infant with a gastric fistula: A contribution to the problem of depression. $J \mathrm{Am}$ Psychoanal Assoc 4:428-452, 1956

25. Brazelton TB: Observations of the neonate. J Am Acad Child Psych 1:38-58, 1962

26. Earls F: Epidemiology of depression. Pediatr Annals 13:23-31, 1984 